Original Research Article

\title{
A comparison study of blood lactate and lactate clearance with SNAP II score as predictors of outcome in sick neonates
}

\author{
Kondle V.K ${ }^{1}$, Gouthami. $\mathbf{P}^{2}$ \\ ${ }^{1}$ Dr.Vamshi Krishna Kondle, Associate Professor, Department of Paediatrics, Kamineni Institute of Medical \\ Sciences, Narkatpally, Nalgonda, ${ }^{2}$ Dr.Gouthami P, Senior Resident, RVM Institute of Medical Sciences, Mulugu \\ Mandal, Siddipet District, Laxmakkapally, Telangana 502279, India.
}

Address for Correspondence: Dr. Gouthami P, E-Mail: gouthami.padugundla88@gmail.com.

\begin{abstract}
Introduction: Necessity of longer stay in NICU reinforces the need for more sensible and specific parameter to evaluate the length of stay and outcome. In order to improve the clinical outcomes in sick neonates, it is crucial to obtain early recognition of those who are at risk of morbidity and mortality and to optimize the clinical decision making in a timely manner and to counsel the parents. Aims \& Objectives: This study was designed to compare and obtain best predictor of outcome irrespective of diagnosis. Materials and Methods: The study was "prospective observational" study, conducted at NICU over 188 sick neonates of Pragna hospitals, Hyderabad in the period of October 2013 to September 2015. Results: Among 188 sick neonates 20 were non survivors, and 168 survived. There was significant correlation between high lactate at admission, low $\mathrm{LAC}_{24}$ of less than $30 \%$ and high SNAP II score at admission with mortality among sick neonates. Neonates with $\mathrm{LAC}_{24}$ of $<30 \%$ had significantly higher requirement of oxygen $\left(\mathrm{p}-0.00^{*}\right)$, fluid support $\left(\mathrm{p}-0.00^{*}\right)$, ionotropes (p$0.0002 * *)$, ventilator support ( $\left.\mathrm{p}-0.0015^{* *}\right)$ and length of stay $\left(\mathrm{p}-0.004^{*}\right)$ than with $\mathrm{LAC}_{24}>60 \%$. There were 23 neonates with initial lactate of more than $9 \mathrm{mmol} / \mathrm{dl}$. 6 out of 23 had $\mathrm{LAC}_{24}$ of less than $30 \%$. 4 out of 6 had $\mathrm{LAC}_{48}$ of more than $30 \%$ yet, all 6 neonates had prolonged duration of stay with an average of 15.3 days. Neonates with high SNAP II score at admission of more than 60 had higher requirement ionotrope, and ventilator support. The area under curve (ROC) revealed poor correlation with overall morbidity. Conclusion: Lactate clearance value of less than $20.4 \%$ at 24 hours of admission could be useful to predict the adverse outcome with significant need for mechanical ventilation, higher oxygen, fluid and inotrope support and prolonged stay in sick neonates irrespective of diagnosis
\end{abstract}

Key words: Sick neonates, Lactate, Lactate clearance, Snap 11 score, Out come

\section{Introduction}

The primary goal for of hemodynamic monitoring is to ensure adequate tissue perfusion and oxygenation and assess the prognosis. Many Variables and popular scores like score for neonatal acute physiology (SNAP) measured in critically ill, have been used to estimate severity of disease, prognosticate morbidity and mortality, but they were influenced by various factors specially in neonates. In recent years two major neonatal severity measures, the score for neonatal acute physiology SNAP-II score [1] and CRIB [2] score focus on measuring and scoring physiological

Manuscript received: $4^{\text {th }}$ June 2017

Reviewed: $15^{\text {th }}$ June 2017

Author Corrected: $24^{\text {th }}$ June 2017

Accepted for Publication: $30^{\text {th }}$ June 2017 derangements. They are compared with invasive laboratory studies like CRP and blood lactate to best predict the outcome and length of stay [3]. Increased blood lactate levels are commonly seen as a consequence of its accumulation from anaerobic metabolism in hypoxic neonates causing hypothermia and decreased survival in neonates. Hyperlactatemia is the sequel of asphyxia, severe lung injury, volume depletion, inefficient vasoregulation and sepsis.

Global tissue hypoxia resulting in systemic inflammatory response syndrome would result in endothelial activation, vasodilation, release of inflammatory mediators and altered coagulation 
ultimately leading to multiorgan dysfunction which is compensated by catecholamine surge and neural regulation [4]. This would result in normalization of vitals but at cellular compromise which is denoted by elevated lactate.Prognostic implications of lactate more than $2 \mathrm{mmol} / \mathrm{dl}$ were studied extensively in adults [5] and neonates pertaining to specific conditions. Recent studies showed low lactate clearance correlates with prolonged stay \& mortality in PICU [6] \& in neonates with sepsis and HIE who underwent brain cooling [7]. There were no studies in neonates to predict the outcome and length of stay irrespective of diagnosis. This study investigated which among initial lactate, lactate clearance and SNAP II score best predicted the outcome among sick neonates.

\section{Aims and Objectives}

Aims- To correlate initial blood lactate, lactate clearance, SNAP II score with outcome in sick neonates. To compare initial lactate, lactate clearance and SNAP II score in predicting the outcome in sick neonates.

Objectives- Obtaining best cut-off for timely lactate clearance percentage for predicting negative outcome and length of stay in sick neonates irrespective of diagnosis.

\section{Materials and Methods}

Centre for study- The study was conducted as a single centre study at Pragna hospitals, Punjagutta,
Andhra Pradesh, India, which is a tertiary care hospital and has got comprehensive paediatric department with neonatal intensive care unit.

Centre for period- October 2013 to September 2015

Type of study- A "prospective observational" study conducted on data collected during above mentioned period from neonatal intensive care unit.

Study sample- 188. The study is approved by hospital ethics and scientific committee.

Inclusion criteria- Sick neonates with respiratory distress, signs of sepsis, acute life threatening event, seizures, renal failure, hypotension and shock with initial blood lactate $>2 \mathrm{mmol}$.

Exclusion criteria- Neonates with congenital abnormalities, Less than 30 week gestation, Post surgical cases, Less than $1 \mathrm{~kg}$ weight

Statistical Analysis- Data is entered in an excel sheet and is analyzed. Continuous variables are assessed with Mann Whitney tests and correlation curves (ROC) were plotted.

ANOVA was used to elaborate significance. SPSS version 20 and WINDOSTAT are used for statistical analysis. $\mathrm{P}$ value of less than 0.05 is considered as significant and is indicated by $(*)$.

\section{Results}

In 188 neonates the mean gestational age of included babies was 37 weeks. About 100 were male babies and 88 were female babies.

Table-1: Demographic variables

\begin{tabular}{|c|c|}
\hline Parameter & Number and range \\
\hline Mean age & 1.4 days [ 0.8 to 3.6 days $]$ \\
\hline Average weight & $2.63 \mathrm{kgs}[1.4$ to $3.8 \mathrm{kgs}]$ \\
\hline Average gestational age & 37 weeks [ 32 to 40 weeks ] \\
\hline Total no. of survivors & 168 \\
\hline Total no. of non survivors & 80 \\
\hline Total no. female neonates & 100 \\
\hline Total no. of male neonates & 11.2 days \\
\hline Average duration of stay in survivors & 4.06 days. \\
\hline Average duration stay in non survivors & \\
\hline
\end{tabular}

Demographic characteristics of study population at admission into NICU (Table-1)

Weight of the enrolled babies at admission had a range of $1.4 \mathrm{kgs}$ to $3.8 \mathrm{kgs}$ with an average age of $2.63 \mathrm{kgs}$. 
Among 168 survivors in $20(10.6 \%)$ survivors, mean lactate value at admission was $13.6 \mathrm{mmol} / \mathrm{dl}$, mean lacatate clearance at 24 hours of admission was -4.08 , and average SNAP II score at admission was 74. Initial lactate and SNAP II score were very high in the non survivors compared to survivors (figure-1).

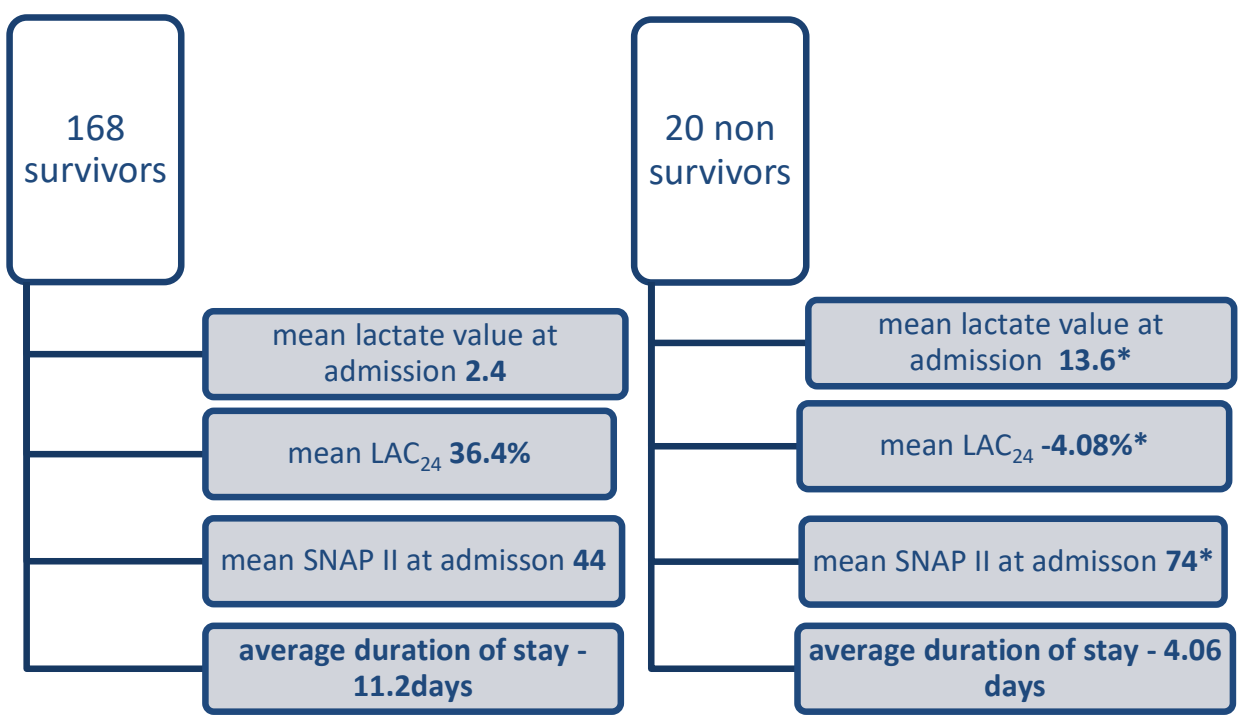

Figure-1: Comparison of lactate variables and SNAP II score between survivors and Nonsurvivors

Table-2: survivor population with lactate level at admission and their outcome.

\begin{tabular}{|c|c|c|c|c|c|c|c|}
\hline $\begin{array}{c}\text { Lactate at } \\
\text { admission }\end{array}$ & $\begin{array}{c}\text { Total } \\
\text { No. of } \\
\text { Neonates }\end{array}$ & $\begin{array}{c}\text { Mean } \\
\text { lactate } \\
\text { value }\end{array}$ & $\begin{array}{c}\text { Mean } \\
\text { oxygen } \\
\text { requirement } \\
\text { in hours }\end{array}$ & $\begin{array}{c}\text { Mean } \\
\text { fluid } \\
\text { support } \\
\text { in hours }\end{array}$ & $\begin{array}{c}\text { Mean } \\
\text { hours of } \\
\text { ionotrope } \\
\text { support }\end{array}$ & $\begin{array}{c}\text { Mean days } \\
\text { of } \\
\text { ventilation } \\
\text { support }\end{array}$ & $\begin{array}{c}\text { Average } \\
\text { length of } \\
\text { stay }\end{array}$ \\
\hline $\begin{array}{c}2- \\
5 \mathrm{mmol} / \mathrm{dl}\end{array}$ & 70 & 3.72 & 76.24 & 96.6 & 36.6 & 4.45 & 7.98 \\
\hline $5-9 \mathrm{mmol} / \mathrm{dl}$ & 75 & 6.48 & 68.5 & 101.95 & 48.5 & 3 & 9.7 \\
\hline$>9 \mathrm{mmol} / \mathrm{dl}$ & 23 & 11.85 & 83.3 & 160 & 102 & 7.6 & 13.2 \\
\hline
\end{tabular}

Average requirement of oxygen, fluid, ionotrope, mechanical ventilation and length of stay with respect to lactate at admission (Table-2)

Requirement of oxygen, fluid, ionotrope support, mechanical ventilation and length of stay in 70 neonates where lactate level at admission was 2-5mmol/dl were 76.24,96.6,36.6,3,7.98.

Table 3: Survived neonates with lactate clearance value at 24 hours and their outcome.

\begin{tabular}{|c|c|c|c|c|c|c|c|}
\hline LAC24 & $\begin{array}{c}\text { Total } \\
\text { No. of } \\
\text { neonates }\end{array}$ & $\begin{array}{c}\text { Mean } \\
\text { value }\end{array}$ & $\begin{array}{c}\text { Mean oxygen } \\
\text { requirement } \\
\text { in hours }\end{array}$ & $\begin{array}{c}\text { Mean fluid } \\
\text { support in } \\
\text { hours }\end{array}$ & $\begin{array}{c}\text { Mean hours } \\
\text { of ionotrope } \\
\text { support }\end{array}$ & $\begin{array}{c}\text { Mean days } \\
\text { of ventilator } \\
\text { support }\end{array}$ & $\begin{array}{c}\text { Average } \\
\text { length of } \\
\text { stay }\end{array}$ \\
\hline$>60 \%$ & 33 & $66.7 \%$ & 30.9 & 65 & 17.9 & 0 & 6 \\
\hline $30-$ & 66 & $47 \%$ & 58 & 110 & 49 & 4 & 10.1 \\
$60 \%$ & & & 85 & 132 & 72.5 & 6.95 & 11.18 \\
\hline$<30 \%$ & 69 & $9.81 \%$ & & & & & \\
\hline
\end{tabular}

Requirement of oxygen, fluid, ionotrope support, mechanical ventilation and length of stay in 33 neonates where lactate level at 24 hours was $>60 \%$ were $30.9,65,17.9,0,6$. 
Table 4: Neonates according to initial SNAP II score at admission and their outcome.

\begin{tabular}{|c|c|c|c|c|c|c|c|}
\hline $\begin{array}{c}\text { SNAP II } \\
\text { at } \\
\text { admission }\end{array}$ & $\begin{array}{c}\text { Total } \\
\text { No. of } \\
\text { Neonates }\end{array}$ & $\begin{array}{c}\text { Mean } \\
\text { SNAP } \\
\text { II } \\
\text { score }\end{array}$ & $\begin{array}{c}\text { Mean oxygen } \\
\text { requirement } \\
\text { in hours }\end{array}$ & $\begin{array}{c}\text { Mean } \\
\text { fluid } \\
\text { support } \\
\text { in hours }\end{array}$ & $\begin{array}{c}\text { Mean } \\
\text { hours of } \\
\text { ionotrope } \\
\text { support }\end{array}$ & $\begin{array}{c}\text { Mean days } \\
\text { of } \\
\text { ventilator } \\
\text { support }\end{array}$ & $\begin{array}{c}\text { Average } \\
\text { length of } \\
\text { stay }\end{array}$ \\
\hline$<30$ & 30 & 13.8 & 12.4 & 46.4 & 6.5 & 0 & 5.06 \\
\hline $30-60$ & 126 & 45.9 & 69.8 & 116.91 & 54.07 & 4.7 & 10 \\
\hline$>60$ & 21 & 70 & 101.9 & 165 & 112 & 12 & 11.9 \\
\hline
\end{tabular}

Requirement of oxygen, fluid, ionotrope support, mechanical ventilation and length of stay in 30 neonates where SNAP II at admission was $<30$ were 12.4,46.4,6.5,0,5.06.

Table 5: Comparison between lactate variables and snap ii score in relation with morbidity determinants.

\begin{tabular}{|c|c|c|c|c|c|}
\hline Parameter & $\begin{array}{c}\text { Oxygen } \\
\text { requirement } \\
\text { (p value) }\end{array}$ & $\begin{array}{c}\text { Fluid } \\
\text { requirement } \\
\text { (p value) }\end{array}$ & $\begin{array}{c}\text { Ionotrope } \\
\text { requirement }\end{array}$ & $\begin{array}{c}\text { Ventilator } \\
\text { requirement } \\
\text { (p value) }\end{array}$ & $\begin{array}{c}\text { Average } \\
\text { duration of } \\
\text { stay (p value) }\end{array}$ \\
\hline $\begin{array}{c}\text { Initial lactate of } \\
>9 \mathrm{mmol} / \mathrm{dl}\end{array}$ & $\begin{array}{c}83.3 \text { hours } \\
(0.3)\end{array}$ & $\begin{array}{c}160 \text { hours } \\
(0.33)\end{array}$ & $\begin{array}{c}102 \text { hours } \\
(0.08)\end{array}$ & $\begin{array}{c}7.6 \text { hours } \\
(0.058)\end{array}$ & 13.2 days \\
\hline $\mathrm{LAC}_{24}<30 \%$ & 85 hours & 132 hours & 72.5 hours & 6.95 hours & 11.18 days \\
& $\left(0.000^{* * *}\right)$ & $\left(0.00^{* *}\right)$ & $\left(0.0002^{* * *}\right)$ & $\left(0.0015^{* *}\right)$ & $\left(0.004^{* *}\right)$ \\
\hline SNAP II $>60$ & 101.9 hours & 165 hours & 112 hours & 12 hours & 11.9 days \\
& $(0.09)$ & $(0.4)$ & $\left(0.0009^{* * *}\right)$ & $\left(0.00089^{* * *}\right)$ & $(0.052)$ \\
\hline
\end{tabular}

Requirement of oxygen in various parameters was 83.3 hours in Initial lactate of $>9 \mathrm{mmol} / \mathrm{dl}, 85$ hours in $\mathrm{LAC}_{24}<30 \%, 101.9$ hours in SNAP II $>60$.

Relation between initial lactate, lactate clearance and outcome- There were 23 neonates with more than $9 \mathrm{mmol} / \mathrm{dl}$ of lactate at admission. 6 neonates had clearance value of less than $30 \%$ at 24 hours. All 6 babies had prolonged stay of more than 15 days and their outcome was negative. The duration of stay in 21 neonates with SNAP II score was shown in figure-2.

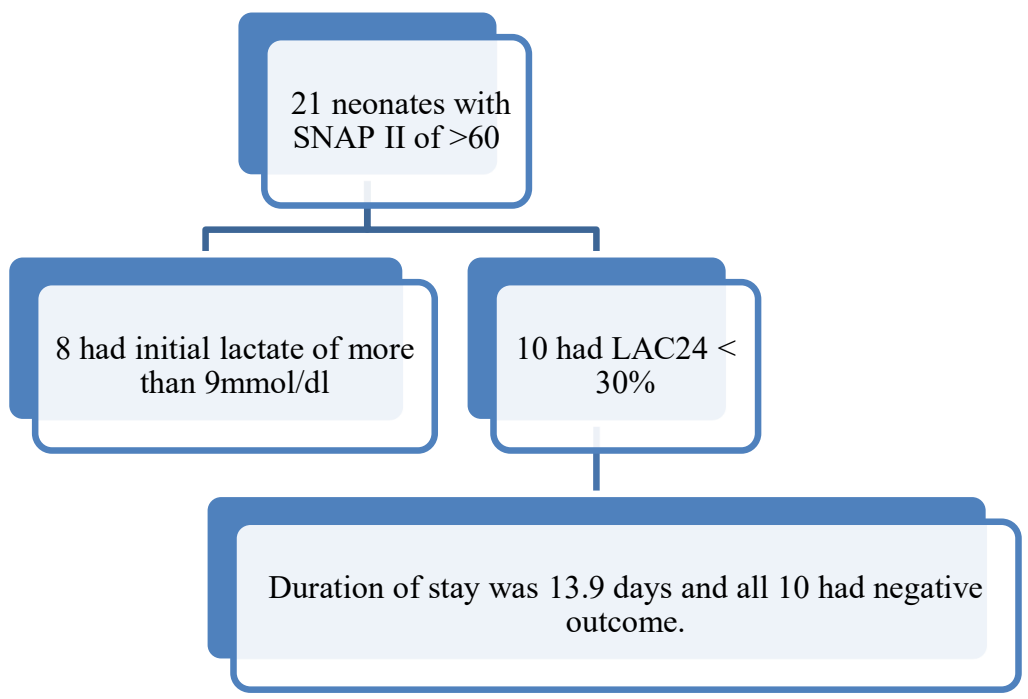

Figure 2: Relation between SNAP II score, lactate variables and outcome Comparison between SNAP II Score AND Lactate Clearance at 24 hours [LAC24] 
Table 6: Comparison between SNAP II Score AND LAC 24

\begin{tabular}{|c|c|c|}
\hline Parameter & LAC ${ }_{\mathbf{2 4}}<\mathbf{3 0} \%$ & SNAP II $>\mathbf{6 0}$ \\
\hline Total no. of neonates & 69 & 21 \\
\hline P value: & & 0.09 \\
\hline oxygen & $0.00^{* *}$ & 0.4 \\
\hline Fluid & $0.001^{* *}$ & $0.0009^{* * *}$ \\
\hline Inotrope & $0.0002^{* * *}$ & $0.0089^{* * *}$ \\
\hline Mechanical ventilation & $0.0015^{* * *}$ & 0.052 \\
\hline Length of stay & $0.004^{*}$ & 0.224 \\
\hline Area under ROC curve & 0.84 & $0.038^{* *}$ \\
\hline Mortality & $0.002^{* * *}$ & \\
\hline
\end{tabular}

In 21 neonates SNAP II score was more than 60 at admission but, lactate clearance were less than $30 \%$ in 69 neonates (41\%). $\mathrm{LAC}_{24}$ and SNAP II score had significant correlation with mortality as depicted in table-6.

The study attempted to establish differences in outcome when SNAP II score and lactate clearance at 24 hours were combined in the small group of 10 neonates and outcome was assessed and compared with clearance and score individually (table-7).

Table 7: Comparison between LAC 24, SNAP II, and SNAP II score and LAC24 combined.

\begin{tabular}{|c|c|c|c|}
\hline Parameter & $\begin{array}{c}\text { SNAP II > 60 combined with LAC24 } \\
\text { less than 30\% }\end{array}$ & LAC 24 < 30\% & SNAP II > 60 \\
\hline $\begin{array}{c}\text { Average no. of hours with } \\
\text { oxygen }\end{array}$ & 110.4 & 85 & 101.9 \\
\hline No. of hours with fluid & 176.19 & 132 & 165 \\
\hline No. of hours with inotropes & 123.4 & 72.5 & 112 \\
\hline No. of days with ventilator & 13.7 & 11.18 & 11.9 \\
\hline Average duration of stay. & 12 & 6.95 & 12 \\
\hline
\end{tabular}

The area under ROC curve for $\mathrm{LAC}_{24}$ of less than $30 \%$ in predicting the negative outcome is 0.8475 , with standard error of 0.05 and confidence interval of 0.95 and probability of $0.002 * *$.(figure- $3,4,5)$

\section{ROC Curve for lactate at admission}

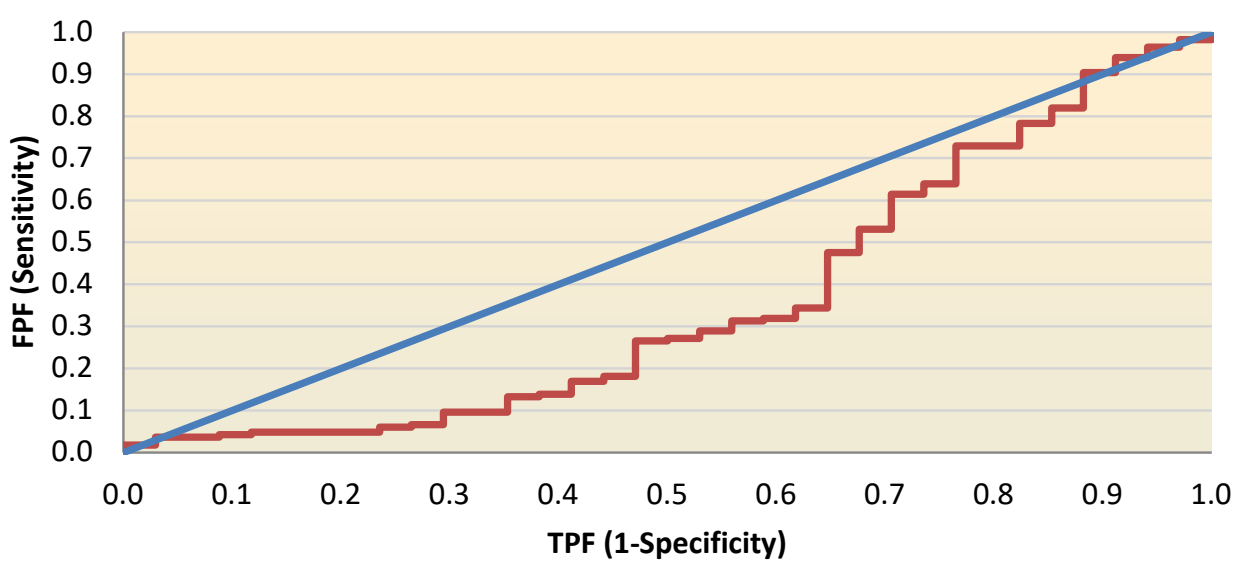

Figure-3: ROC curve of lactate at admission in predicting outcome $(r=0.346)$ 


\section{ROC Curve for SNAP II AT ADMISSION}

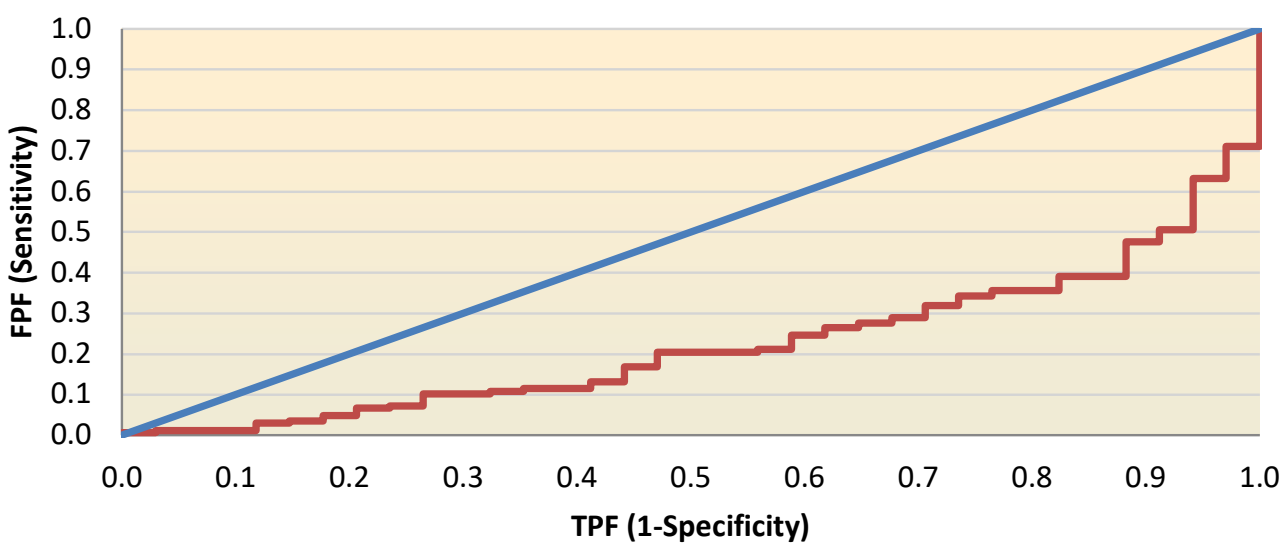

Figure-4: ROC curve of SNAP II score in predicting outcome $(r=0.22)$

\section{ROC Curve for LAC 24}

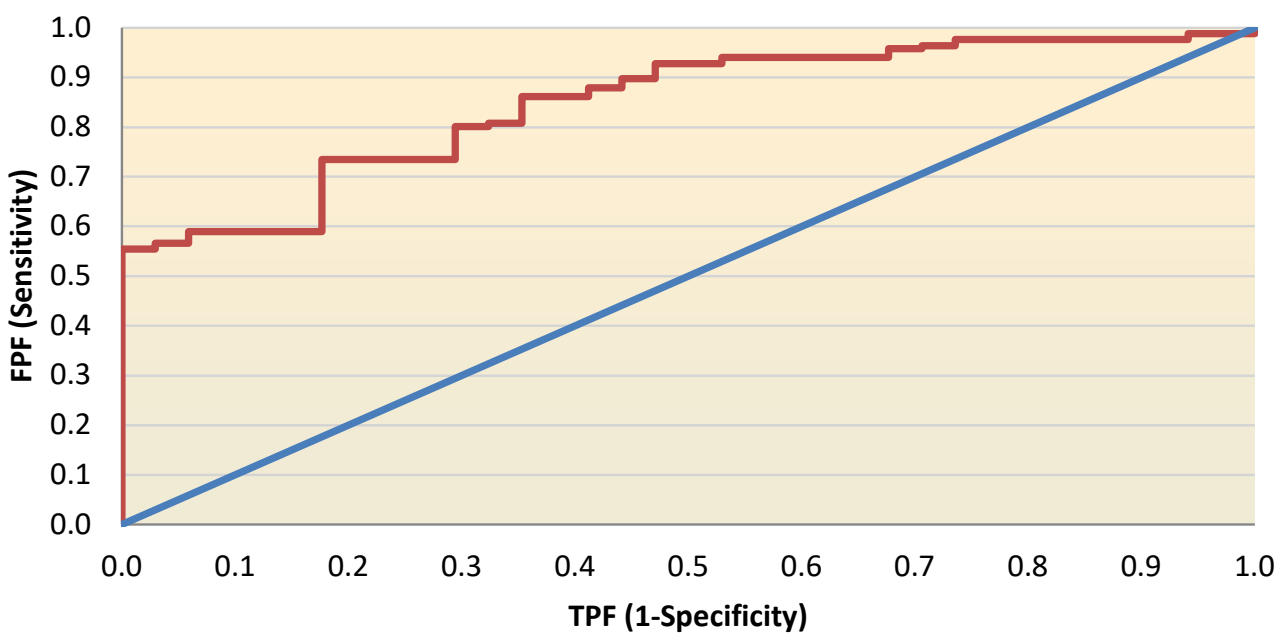

Figure 5: Correlation between $\mathrm{LAC}_{24}<30 \%$ and Negative Outcome

Timely cut off of lactate clearance value at 24 hours in predicting the outcome

Lactate clearance value of $\mathbf{2 0 . 4 0 8 \%}$ at 24 hours of admission $\left(\mathrm{LAC}_{24}\right)$ was obtained as cut off value using logistic regression in predicting negative outcome with positive predictive value of $95.3 \%$ and negative predictive value of $38.8 \%$. 44 neonates had clearance at 24 hours of admission $\left(\mathrm{LAC}_{24}\right)$ less than $20.4 \%$. Average duration of oxygen requirement in them was for 85 hours, fluid support for 140 hours, ionotrope requirement for 72 hours and required 7.6 days of mechanical ventilation. All neonates with LAC 24 less than $20.4 \%$ had an average duration of stay for 13.6 days.

\section{Discussion}

Blood lactate and mortality- The study of lactate levels in relation with in risk stratification and mortality rate helped in assessing the prognosis of the critically ill. Various studies used a ROC curve to define the lactate level cutoff point with a better sensitivity and specificity to predict early death but there is currently no consensus for cut off value for blood lactate value in newborns. In contrast, for 
adult patients, the reference values of blood lactate have already been established, and levels up to2 $\mathrm{mmol} / \mathrm{L}$ are considered normal. Initial lactate values of more than $5 \mathrm{mmol} / \mathrm{dl}$ [8] was significantly associated with negative outcome in pediatric patients with septic shock.

High lactate value of more than $9 \mathrm{mmol} / \mathrm{dl}$ was associated with significant mortality in the study. However, the fact that the half-life of lactate is not known, might explain the reason why a single measurement of lactate performed during the first hours of life does not reflect the events that occur after 24 to 48 hours of hospitalization [9].

Lactate clearance and mortality- Lactate clearance has shown more promise in predicting mortality. Two studies in adult patients with shock showed lactate clearance of $<10 \%$ was related to mortality [10]. Our findings suggest that lactate clearance in the first 24 hour period of disease presentation, is an independent and superior variable associated with mortality.

Out of 188, 20 were non survivors, and 168 survived. Mean lactate at admission, lactate clearance at 24 hours, and SNAP II scores were compared between survivors and non survivors. Blood lactate levels in non-survivors were elevated and persistently high, while blood lactate levels in survivors decreased and normalize within $24 \mathrm{~h}$ which supports the importance of the time course of lactate levels in predicting the outcome among the survivors.

There was significant correlation between high lactate at admission, low $\mathrm{LAC}_{24}$ of less than $30 \%$ and high SNAP II score at admission with mortality among sick neonates.

Lactate and morbidity- Neonates with initial lactate of more than $9 \mathrm{mmol} / \mathrm{dl}$ had significantly higher requirement of fluids and inotrope compared to those with lactate value of less than $9 \mathrm{mmol} / \mathrm{dl}$. There was no correlation with other morbidity determinants. The predictive value is less and the area under ROC shows poor correlation.

Lactate clearance and morbidity- There was significant correlation between lactate clearance, outcome and prognosis. Hence, clearance directed therapy with respect to time is being investigated extensively among adults and pediatric population. There is no such studies in general neonatal ICU population to predict the outcome irrespective of type of illness. In septic patients, a lactate clearance directed therapy in the first 6 hours appeared as efficient as $\mathrm{ScvO} 2$ [11]. In general adult ICU population an $8 \mathrm{hr}$ therapy adaptation to lactate clearance reduced mortality rate in patients with hyperlactatemia compared with standard therapy [12].

Absence of lactate clearance to less than 20\% after 8 hours of resuscitation lead to therapy intensification even in those who reach standard hemodynamically target [13]. Less than $30 \%$ clearance among pediatric population within first 24 hours of admission correlated significantly with mortality [14]. The nonsurvivor group of the present study also had lactate clearance of less than $30 \%$ at 24 hours which was significantly different from mean value among survivors.

The morbidity was high among the survived neonates with lactate clearance of less than $30 \%$ at 24 hours with significantly greater need of oxygen, fluid, inotrope, and mechanical ventilation.

Length of stay- There were 23 neonates with initial lactate of more than $9 \mathrm{mmol} / \mathrm{dl}$. out of which, 17 babies had lactate clearance of more than $30 \%$ after receiving treatment for 24 hours and only 6 had LAC24 of less than 30\%. All 6 neonates had negative outcome and prolonged duration of stay with an average of 15.3 days.

SNAP II score and morbidity- SNAP II score at admission was more than 60 in 21 neonates. They only had significant difference in terms of inotrope support and mechanical ventilation. The area under curve (ROC) of logistic regression was low with poor correlation with outcome among sick neonates.

These results of the study are comparable with recent studies on SNAP II score, that the score alone is poor predictor of morbidity [15]. The reason may be the fact that the components of score like, $\mathrm{pH}$, urine output, presence of seizures etc. contribute to the morbidity individually with respect to diagnosis. Hence, SNAP II alone might have a role in assessing the severity of the illness but not in assessing the outcome. 
SNAP II combined with LAC 24- Among 21 neonates who had SNAP score of more than 60,10 neonates also had lactate clearance less than $30 \%$ hours of at 24 hours of admission.

The average duration of oxygen, fluid, inotrope, mechanical ventilator support were higher than in neonates with $\mathrm{LAC}_{24}$ of less than $30 \%$. However due to variable sample in each group correlation could not be established.

Timely cut off- This is the first study to obtain best cut off value of lactate clearance to predict outcome and length of stay among group 3 neonates with lactate clearance of less than $30 \%$ at 24 hours using logistic regression.

Neonates with lactate celarance of $20.4 \%$ at 24 hours of admission had negative outcome with an average of 74 hours of mechanical ventilation and prolonged stay. The area under ROC curve was significant (0.84) with respect to lactate clearance and negative outcome. In our study PPV, NPV and ROC curve analysis for morbidity prediction of lactate clearance are comparable to Hatheril et al findings at 24 hours in pediatric ICU [16]

Though low lactate clearance is correlated with mortality and morbidity in various studies, this is the first study to quantify the value in relation with time and outcome among critically ill neonates irrespective of diagnosis.

High lactate clearance in the early hospital course may indicate a resolution of hypoxia at cellular level. So clinicians should interpret clearance less than $30 \%$ at $24 \mathrm{hrs}$ with normalized vitals or SNAPII score or as a warning, that the neonates actually did not clinically improve or even deteriorate. Our data suggest that lactate clearance at 24 hours is more sensible and specific to predict negative outcome with significant correlation than initial lactate, lactate clearance at 48 hours, SNAP II score and represents a useful and clinically obtainable surrogate marker of tissue hypoxia and disease severity, independent of high initial lactate and high SNAP II score.

Lactate clearance is the most proximal presentation in sick neonates. Hence, this study adds the importance of its inclusion in addition to SNAP II score and other scores in assessing sick neonates.

\section{Conclusions}

Initial lactate value of more than $9 \mathrm{mmol} / \mathrm{dl}$ had poor correlation with outcome. SNAP II score of more than 60 is not well correlated with outcome. Neonates with low lactate clearance of less than $30 \%$ had significantly greater need of oxygen, fluid, ionotrope, ventilator support and prolonged stay for more than 13 days irrespective of diagnosis. Lactate clearance of $20.4 \%$ at 24 hours of admission can be used as cut off marker of negative outcome with good correlation in sick neonates irrespective of diagnosis.

Funding: Nil, Conflict of interest: None initiated, Perission from IRB: Yes

\section{References}

1. Vasudevan A, Malhotra A, Lodha R, Kabra SK. Profile of neonates admitted in paediatric ICU and validation of Score or Neonatal Acute Physiology (SNAP). Indian Pediatric 2006;Apr:43:344-348.

2. The international Neonatal Network. The CRIB (Clinical Risk Index for Babies) score: a tool for assessing initial neonatal risk and comparing performance of neonatal intensive care units. Lancet 1993; 342:193-198.

3. Pollack MM, Koch MA, Bartel DA, Rapoport I, Dhanireddy R, El-Mohandes AA, Harkavy K, Subramanian KN. A comparison of neonatal mortality risk prediction models in very low birth weight infants. Pediatrics. 2000 May; 105(5): 1051-7.

4. Karimova A, Pinsky DJ. The endothelial response to oxygen deprivation: biology and clinical implications. Intensive Care Med. 2001 Jan; 27 (1):19-31.

5. Hack CE, Zeerleder S. The endothelium in sepsis: source of and a target for inflammation. Crit Care Med. 2001 Jul;29(7 Suppl):S21-7.

6. Munde A, Kumar N, Beri RS, Puliyel JM. Lactate clearance as a marker of mortality in pediatric intensive care unit. Indian Pediatr. 2014 Jul;51(7):565-7.

7. RE Musson, SJ Clark, R Kachroo, S Didier and M Smith. Arch Dis Child Fetal Neonatal Ed 2013 98: A61, doi: 10.1136. 
8. Kana Ram, Urmila Jhamb, Vinod K. Gupta. Indian Journal of CriticalCareMedicine:2011;15: 2.

9. Deshpande SA, Platt MP. Association between blood lactate and acid-base status and mortality in ventilated babies. Arch Dis Child Fetal Neonatal Ed. 1997 Jan;76(1):F15-20.

10. Marty P, Roquilly A, Vallée F, Luzi A, Ferré F, Fourcade O, Asehnoune K, Minville V. Lactate clearance for death prediction in severe sepsis or septic shock patients during the first 24 hours in Intensive Care Unit: an observational study. Ann Intensive Care. 2013 Feb 12;3(1):3. doi: $10.1186 /$ 2110- 5820-3-3.

11. Jones AE, Shapiro NI, Trzeciak S, Arnold RC, Claremont HA, and Kline JA: Lactate clearance vs central venous oxygen saturation as goals of early sepsis therapy: a randomized clinical trial. JAMA 2010, 303(8):739-746.

12. Jansen TC, van Bommel J, Schoonderbeek FJ, Sleeswijk Visser SJ, van der Klooster JM, Lima AP, Willemsen SP, Bakker J; LACTATE study group. Early lactate-guided therapy in intensive care unit patients: a multicenter, open-label, randomized controlled trial. Am J Respir Crit Care Med. 2010 Sep 15;182(6):752-61. doi: 10.1164/ rccm. 200912-19180C. Epub 2010 May 12.

13. Weil MH, Afifi AA. Experimental and clinical studies on lactate and pyruvate as indicators of the severity of acute circulatory failure (shock). Circulation. 1970 Jun;41(6):989-1001.

14. Trzeciak S, Dellinger RP, Chansky ME, Arnold RC, Schorr C, Milcarek B, Hollenberg SM, Parrillo JE. Serum lactate as a predictor of mortality in patients with infection. Intensive Care Med. 2007 Jun; 33 (6):970-7. Epub 2007 Mar 13.

15. Helal NF, Samra NM, Abdel Ghany EAG et al: SNAP II in neonatal sepsis, J Neonatal boil; 2013;2:121.

16. Jan Bakker, Maarten WN Nijsten and Tim C Jansen. Annals of Intensive Care 2013, 3:12 doi: 10. 1186/2110-5820-3-12 Review.

\section{How to cite this article?}

Kondle V.K, Gouthami. P. A comparison study of blood lactate and lactate clearance with SNAP II score as predictors of outcome in sick neonates. J PediatrRes.2017;4(06):388-396.doi:10.17511/ijpr.2017.i06.07. 